\title{
ANALISIS PENGARUH INFRASTRUKTUR TERHADAP KETIMPANGAN PEMBANGUNAN EKONOMI WILAYAH DI PROVINSI ACEH
}

\author{
Analysis of Infrastructure Effect on Disparity Economic \\ Development Area in Aceh Province
}

Muhammad Iqbal' ${ }^{1}$, Amzul Rifin ${ }^{1}$, Bambang Juanda ${ }^{1}$

Diterima: 21 Juli 2017 Disetujui: 10 Agustus 2017

\begin{abstract}
Abstrak: Pembangunan infrastruktur merupakan aspek penting dalam pertumbuhan ekonomi. Pembangunan infrastruktur yang baik akan menjamin efisiensi, memperlancar pergerakan barang dan jasa, dan meningkatkan nilai tambah perekonomian, dan juga sebagai faktor pendorong produktivitas daerah. Tujuan penelitian ini adalah menganalisis tingkat ketimpangan antar wilayah dan menganalisis pengaruh ketersediaan infrastruktur terhadap ketimpangan wilayah di Provinsi Aceh. Metode analisis yang digunakan adalah Indeks Williamson dan Data Panel. Hasil penelitian menunjukkan bahwa variabel yang signifikan dapat mempengaruhi ketimpangan pembangunan ekonomi wilayah di Provinsi Aceh adalah variabel listrik yang berpengaruh sebesar -0,012594 dan variabel pendidikan yang berpengaruh sebesar $-0,060347$. Variabel yang tidak berpengaruh signifikan adalah jalan berpengaruh sebesar -0,009463 dan variabel kesehatan berpengaruh sebesar 0,046067.
\end{abstract}

\section{Kata kunci : Wilayah, Pembangunan Ekonomi, Infrastruktur, Ketimpangan}

\begin{abstract}
Infrastructure development is an important aspect of economic growth. Good infrastructure development will ensure efficiency, facilitate the movement of goods and services, and increasing the added value of the economy, as well as factors driving the productivity of the area. The purpose of this study is to analyze the level of inequality between regions and analyze the effect of infrastructure availability on regional inequality in Aceh Province. The analysis method used is Williamson Index and Panel Data. The results showed that the significant variables can affect the imbalance of economic development of the region in Aceh province is the variable of electricity that has an effect of -0.012594 and the influential educational variables of -0.060347 . Variables that have no significant effect is the road effect of -0.009463 and health variables affecting 0.046067 .
\end{abstract}

Keywords: Region, Economic Development, Infrastructure, disparity

\section{PENDAHULUAN}

Pembangunan ekonomi dilakukan oleh negera guna meningkatkan kesejahteraan masyarakat dengan cara menyediakan infrastruktur yang baik dan merata, tingkat pendidikan masyarakat yang tinggi, teknologi yang semakin ber-inovasi dan berkembangnya perusahan-perusahan. Menurut Todaro (2000) usaha pembangunan ekonomi mempunyai tujuan utama yaitu menciptakan pertumbuhan yang tinggi, menghapus dan mengurangi tingkat kemiskinan, ketimpangan pendapatan dan tingkat pengangguran. Salah satu cara untuk memberikan pendapatan guna memenuhi kebutuhan masyarakat adalah kesempatan kerja bagi masyarakat. 
Rustiadi et al (2009) menyatakan bahwa pendekatan pembangunan yang cenderung mengabaikan terjadinya ketimpangan atau kesenjangan pembangunan antar wilayah karena sangat menekankan pada pertumbuhan ekonomi makro, sehingga investasi dan sumberdaya terserap dan terkonsentrasi di perkotaan dan pusat pertumbuhan. Ketimpangan wilayah pada akhirnya menimbulkan permasalahan dalam konteks makro yang sangat merugikan proses pembangunan yang ingin dicapai dalam suatu negara. Buruknya distribusi dan alokasi pemanfaatan sumberdaya yang menciptakan inefisiensi dan tidak optimalnya sistem ekonomi di satu sisi disebabkan oleh ketidakseimbangan pembangunan antar wilayah.

Pembangunan ekonomi daerah dilakukan oleh Pemerintah Daerah untuk merangsang pertumbuhan ekonomi wilayah dengan cara membentuk pola kemitraan dengan sektor swasta dalam pengelolaan sumber daya guna membuka lapangan kerja baru dan peningkatan pendapatan masyarakat. Menurut Masykur (2000) keberhasilan pengembangan wilayah dilihat sebagai kesuksesan pembangunan wilayah dengan tiga indikator. Indikator pertama adalah produktivitas, yang dapat diukur dari perkembangan kinerja suatu institusi beserta aparatnya. Indikator kedua adalah efisiensi, yang terkait dengan meningkatnya kemampuan teknologi/sistem dan kualitas sumber daya manusia dalam pelaksanaan pembangunan. Indikator ketiga adalah partisipasi masyarakat yang dapat menjamin kesinambungan pelaksanaan suatu program di suatu wilayah.

Setiap upaya percepatan pertumbuhan ekonomi akan membuka celah terjadinya ketimpangan pendapatan antargolongan masyarakat ataupun interregional. Oleh karena itu, setiap upaya untuk meningkatkan pertumbuhan ekonomi harus disertai dengan upaya untuk mengeliminir setiap celah yang memungkinkan terjadinya ketimpangan pendapatan. Pembangunan infrastruktur mempunyai hubungan yang erat dengan pengentasan kemiskinan dan peluang usaha, secara umum Joint Flag Study IBRD dan ADB, 2005 (dalam Muljono, 2010) dalam gambar 1.

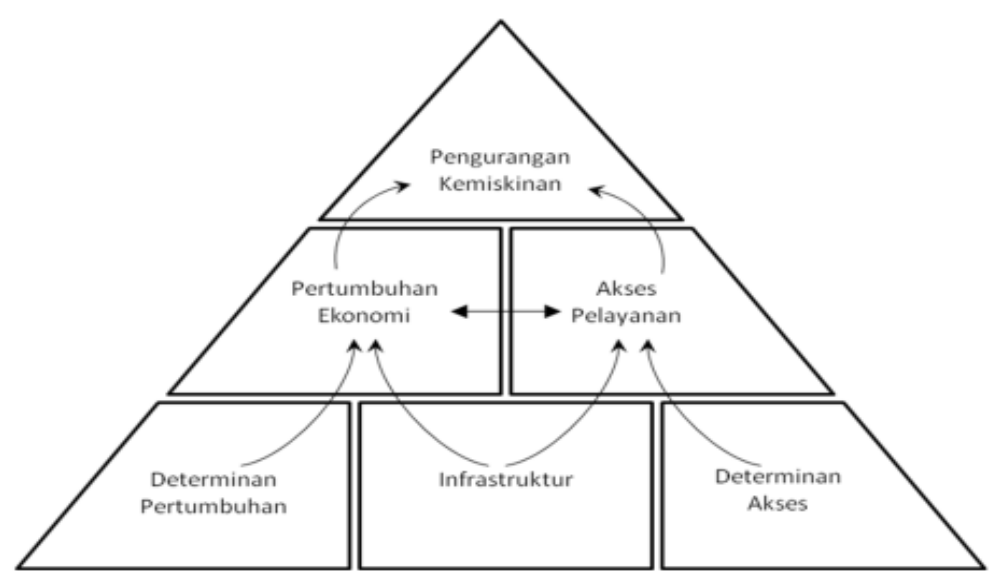

Sumber : IBRD dan ADB, 2005 dalam Muljono 2010

Gambar 1. Linkages antara Infrastruktur, Pengurangan Kemiskinan dan Pertumbuhan

Pembangunan infrastruktur merupakan aspek penting dalam pertumbuhan ekonomi dan aspek pelayanan. Dengan adanya infrastruktur yang baik berakibat baik pula terhadap pertumbuhan ekonomi, sehingga terciptanya lapangan kerja baru. Dan dukungan akses layanan yang baik menjadikan tingkat kemiskinan semakin menurun dan pendapatan perkapita semakin meningkat. Infrastruktur berperan sangat penting dalam pertumbuhan ekonomi suatu daerah, dengan tersedianya infrastruktur yang baik dapat meningkatkan hasil 
produksi, membuka lapangan kerja baru, mengurangi kemiskinan dan meningkatkan kesejahteraan masyarakat.

Suatu daerah yang mempunyai infrastruktur yang baik akan memudahkan masyarakat dalam mengaksesnya. Misalnya infrastruktur jalan, jalan merupakan aspek penting dalam pertumbuhan ekonomi suatu wilayah, dengan tersedianya jalan yang baik akan memudahkan distribusi barang dan orang, sehingga biaya distribusi lebih rendah dan harga dapat bersaing dipasaran. Selain infrastruktur ekonomi, infrastruktur sosial juga sangat penting untuk meningkatkan kualitas hidup masyarakat, contohnya pusat-pusat pendidikan, dan kesehatan.

Pembangunan infrastruktur yang baik akan menjamin efisiensi, memperlancar pergerakan barang dan jasa, dan meningkatkan nilai tambah perekonomian. Ketersediaan infrastruktur merupakan salah satu faktor pendorong produktivitas daerah. Keberadaan infratsruktur seperti jalan raya dan jembatan akan mampu membuka akses bagi masyarakat dalam melaksanakan aktivitas ekonomi. Kelancaran transportasi darat ditentukan oleh kualitas dan kuantitas panjang jalan yang menghubungkan suatu daerah dengan daerah lainnya. Total panjang ruas jalan yang berstatus jalan provinsi $1.580,42 \mathrm{~km}$ sementara jalan nasional sepanjang $1.803,35 \mathrm{~km}$. Kerapatan jalan yang menunjukkan rasio panjang jalan terhadap luas wilayah di Provinsi Aceh menempati urutan 19 dibandingkan provinsi lain di Indonesia. (Bappeda Aceh, 2015)

Infrastruktur kedua yang dapat mendorong produktivitas daerah adalah jaringan listrik. Menurut Bappeda Aceh (2015), konsumsi listrik Provinsi Aceh tergolong rendah yaitu 400,60 KWh, dan dibawah rata-rata tingkat konsumsi listrik nasional yaitu 787,60 KWh. Defisiensi terhadap infrastruktur kelistrikan di ukur dengan melihat korelasi antara PDB Perkapita dengan tingkat konsumsi listrik. Semakin tinggi pendapatan perkapita akan berdampak pada tingginya tingkat konsumsi pada suatu daerah. Provinsi Aceh berada jauh dibawah posisi provinsi lain yang tingkat pendapatan perkapitanya sama. Dengan demikian, salah satu masalah di Aceh adalah ketersediaan jaringan listrik.

Salah satu penyebab kurang tumbuh dan berkembangnya perekonomian di Aceh adalah konsumsi listrik masih rendah bahkan dibawah rata-rata konsumsi listrik nasional. Karena hubungan antara konsumsi listrik dan pendapatan per kapita sangat erat juga, sama halnya dengan hubungan infrastruktur jalan.

Selain infrastruktur ekonomi, infrastruktur sosial juga dapat mempengaruhi ketimpangan pembangunan ekonomi. Pendapatan per kapita dapat dipengaruhi oleh tingkat pendidikan dan kesehatan masyarakat di suatu wilayah. Infrastruktur sosial yang dapat mempengaruhi tingkat pertumbuhan ekonomi adalah tingkat pendidikan.

Infratruktur sosial yang pertama adalah pendidikan, yang merupakan sarana dalam peningkatan sumberdaya manusia bagi pembangunan. Budaya belajar disekolah diharapkan mampu menjembatani kesenjangan budaya belajar di masyarakat dengan melaksanakan penyelenggaraan pendidikan di daerah terpencil. Tingkat kewajaran dalam proses belajar mengajar indikator pengukurnya yaitu dengan melakukan perbandingan antara fasilitas pendidikan dengan fasilitas tenaga pengajar dan tenaga didik. Secara keseluruhan tingkat pendidikan di Aceh menunjikkan tren meningkat, aka tetapi angka Partisipasi Sekolah (APS) pada usia 7-12 tahun dan 13-15 tahun (pendidikan dasar) antar kota dan kabupaten di Provinsi Aceh pada tahun 2013 belum cukup merata. Pada tahun 2013 rata-rata APS Provinsi Aceh sebesar 99,66 persen untuk usia 7-12 tahun dan 95,2 persen untuk usia 13-15 tahun. Kabupaten Simeuleu dan Kota Langsa merupakan kabupaten/kota dengan APS terendah di Provinsi Aceh. Untuk penduduk usia 16-18 tahun (tingkat SMA) APS Provinsi Aceh sebesar 80,89. (Bappeda Aceh, 2015). Sesuai dengan pernyataan BPS (2016), peningkatan kualitas pendidikan yang pada akhirnya akan meningkatkan kualitas SDM yang tangguh, dapat bersaing di era globalisasi dan mampu mendongkrak perekonomian berbasis kerakyatan. 
Peningkatan kualitas SDM sekarang ini lebih difokuskan kepada penduduk kelompok usia sekolah (7-24 tahun) untuk mengecap pendidikan.

Infrastruktur sosial yang kedua yang sangat penting dalam pembangunan ekonomi adalah infrastruktur kesehatan. Faktor kesehatan merupakan salah satu kebutuhan penting untuk pembangunan manusia. Kulaitas dan kuantitas fasilitas kesehatan di Aceh mengalami perbaikan, sehingga diharapkan pelayanan yang lebih baik da memuaskan bagi masyarakat. Salah satu indikator kesehatan yaitu angka kematian bayi, pada tahun 2012 angka kematian bayi di Aceh sebanyak 47 kematian per 1000 kelahiran baru, sedangkan pada tingkat nasional menunjukkan 34 kematian per 1000 kelahiran baru. Bila dibandungkan dengan tahun 2007 angka ini mengalami peningkatan, yaitu 25 kematian per 1000 kelahiran baru. Persentase kelahiran bayi yang dibantu oleh tenaga kesehatan pada tahun 2014 mencapai 91,41 persen dengan penolong kelahiran bayi adalah bidan dan dokter. Kabupaten Gayo lues, Nagan Raya, Subulussalam, Aceh Singkil, Simeulue, Aceh Timur, Kota Langsa, dan Aceh Jaya masih terdapat kelahiran yang dibantu oleh bukan tenaga kesehatan, akan tetapi jumlahnya sangat kecil. Jumlah pelayanan kesehatan di Aceh terdiri atas 50 rumah sakit, 337 puskesmas, 856 puskesmas pembantu, serta 2.402 pondok bersalin desa pada tahun 2014 . Sementara itu, untuk menjangkau daerah pedesaan fasilitas kesehatan yang disediakan pemerintah adalah puskesmas keliling sebanyak 352 mobil dan 10 perahu bermotor. Jumlah puskesmas terbanyak terdapat di Kabupaten Aceh Besar, sebanyak 28 puskesmas, sedangkan paling sedikit terdapat di Kota Langsa dan Subulussalam masing-masing 5 puskesmas. (Bappeda Aceh, 2015)

Salah satu solusi mengatasi ketimpangan wilayah dengan cara pemerataan pembangunan infrastruktur. Dengan adanya infrastruktur yang memadai dan baik akan meningkatkan kesejahteraan masyarakat baik dari aspek ekonomi, sosial, budaya, informasi dan lain-lain. Sesuai dengan uraian di atas, maka tujuan penelitian ini adalah: (1) Menganalisis tingkat ketimpangan antar wilayah ekonomi di Provinsi Aceh. (2) Menganalisis pengaruh ketersediaan infrastruktur terhadap ketimpangan wilayah di Provinsi Aceh.

\section{METODE PENELITIAN}

Penelitian ini dilaksanakan dari bulan Agustus sampai bulan Desember 2016, dengan menggunakan data sekunder (tahun 2011 - 2015) di Provinsi Aceh yang terdiri dari 23 kabupaten/kota. Data yang meliputi data PDRB Kabupaten/kota, jumlah penduduk, data infrastruktur Ekonomi dan sosial Kabupaten/Kota dan lain sebagainya.

Data yang digunakan pada penelitian ini adalah data sekunder yang diperoleh dari berbagai sumber seperti studi pustaka, Badan Pusat Statitik (BPS), Badan Perencanaan Daerah Aceh (Bappeda Aceh) dan data lain yang terkait.

\section{Analisis Ketimpangan Pembangunan Ekonomi}

Analisis ketimpangan pembangunan dilakukan dengan menggunakan Analisis Indeks Williamson.

$$
V w=\frac{\sqrt{\sum_{i}\left(y_{i}-\bar{y}\right)^{2}\left(f_{i}: n\right)}}{\bar{y}}
$$

Keterangan:

$\begin{array}{ll}\text { Vw } & \text { : Indeks ketimpangan Williamson Provinsi Aceh } \\ \text { yi } & \text { : PDRB perkapita kabupaten/kota i } \\ \bar{y} & \text { : Rata-rata PDRB perkapita Provinsi Aceh } \\ \text { fi } & \text { : jumlah penduduk kabupaten/kota i } \\ \mathrm{n} & \text { : Jumlah penduduk Provinsi Aceh }\end{array}$




\section{Pengaruh Infrastruktur terhadap Ketimpangan Ekonomi Wilayah}

Dalam penelitian ini, faktor ketimpangan pembangunan ekonomi analisis yang digunakan adalah Indeks Gini Ratio. Dalam hal ini nilai Indeks Gini Ratio sudah tersedia dari BPS Provinsi Aceh. Model persamaan data panel dapat dioperasikan sebagai berikut:

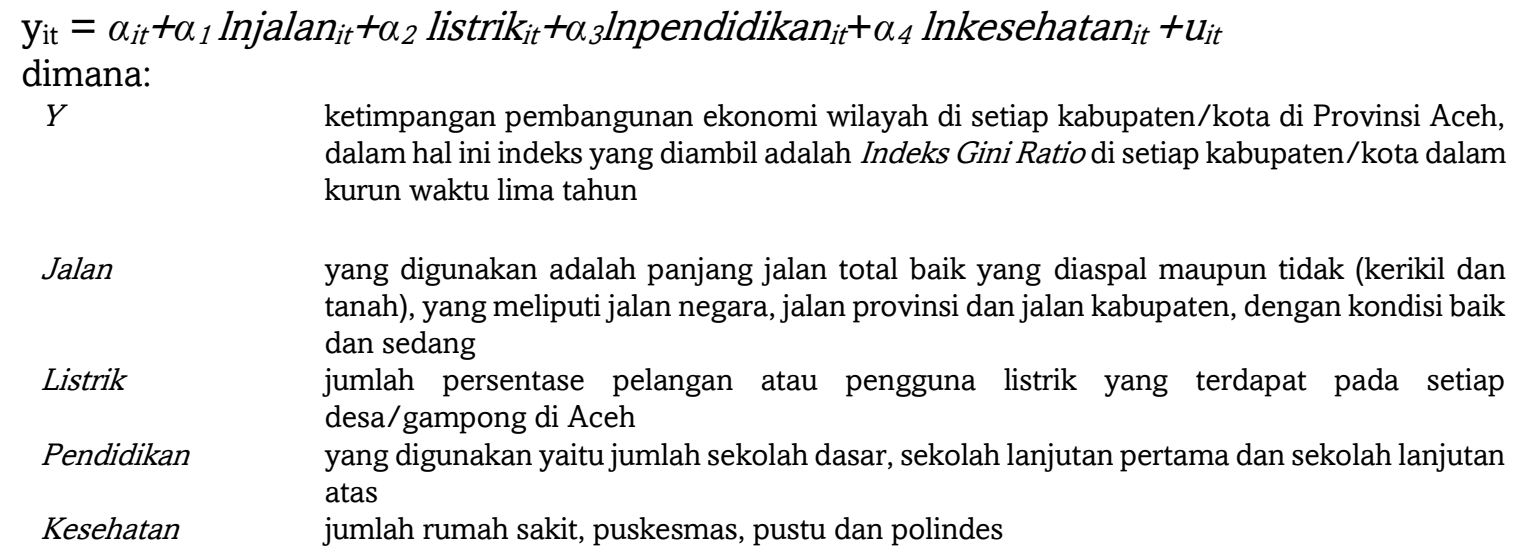

\section{HASIL DAN PEMBAHASAN}

\section{Analisis Ketimpangan Pembangunan Ekonomi}

Ketimpangan pembangunan antar wilayah di Provinsi Aceh disebabkan oleh beberapa faktor salah satunya adalah kondisi geografis wilayah yang berbeda-beda dan faktor jarak dengan pusat pertumbuhan ekonomi dan pusat pemerintahan sehingga mempengaruhi kebijakan pemerintah dalam pembangunan. Kondisi geografis, ketersediaan infrastruktur dan kebijakan pembangunan memicu timbulnya ketimpangan antar wilayah. Beberapa daerah dapat lebih maju dan berkembang dengan cepat karena aktivitas ekonominya berkembang pesat dan menjadi tempat pertumbuhan ekonomi dan ada beberapa daerah yang kurang berkembang kerena berbagai faktor. Hal ini menyebabkan ketimpangan wilayah. Dalam mengatahui seberapa besar ketimpangan wilayah maka digunakan analisis indeks Williamson. Indeks Williamson menggunakan nilai PDRB perkapita dan jumlah penduduk tiap kabupaten/kota di Provinsi Aceh. Data yang diambil mulai tahun 2011 sampai dengan tahun 2015 dengan melibatkan 23 kabupaten/kota. Hasil analisis indeks Williamson dapat dilihat pada Tabel 1.

Tabel 1. Nilai Indeks Williamson periode 2011-2015

\begin{tabular}{ccc}
\hline Tahun & Indeks Williamson & Perubahan \\
\hline 2011 & 0,46 & - \\
2012 & 0,45 & -0.01 \\
2013 & 0,43 & $-0,02$ \\
2014 & 0,41 & $-0,02$ \\
2015 & 0,40 & $-0,01$ \\
Rata-rata & 0,43 & - \\
\hline
\end{tabular}

Sumber: Hasil analisis

Berdasarkan perhitungan dari indeks Williamson dapat diketahui bahwa tingkat ketimpangan di Provinsi Aceh selama kurun waktu 5 tahun semakin menurun, hal ini menandakan bahwa tingkat ketimpangan semakin rendah dari tahun ke tahun. Rata-rata nilai Indeks Williamson yang terjadi di Provinsi Aceh sejak tahun 2011 sampai 2015 adalah 0,43. Indeks Williamson memiliki sebaran nilai dari 0 sampai 1, apabila nilai Indeks Williamson 
semakin mendekati nol maka ketimpangan semakin rendah dan sebaliknya apabila nilai Indeks Williamson mendekati satu maka ketimpangan sangat tinggi disuatu wilayah.

Nilai indeks Williamson mengalami penurunan dari waktu ke waktu, dari tahun 2011 indeks Williamson sebesar 0,46 menurun menjadi 0,45 pada tahun 2015, terjadi perubahan sebesar 0,01 seterusnya menjadi 0,40 pada tahun 2015. Kalau dilihat dari tahun 2011 sampai tahun 2015 terjadi perubahan nilai indeks sebesar -0,05. Pada tahun 2013 dan tahun 2014 terjadi perubahan yang agak sedikit lebih tinggi sebesar $-0,02$ dibandingkan dengan tahun 2012 dan tahun 2015 sebesar $-0,01$.

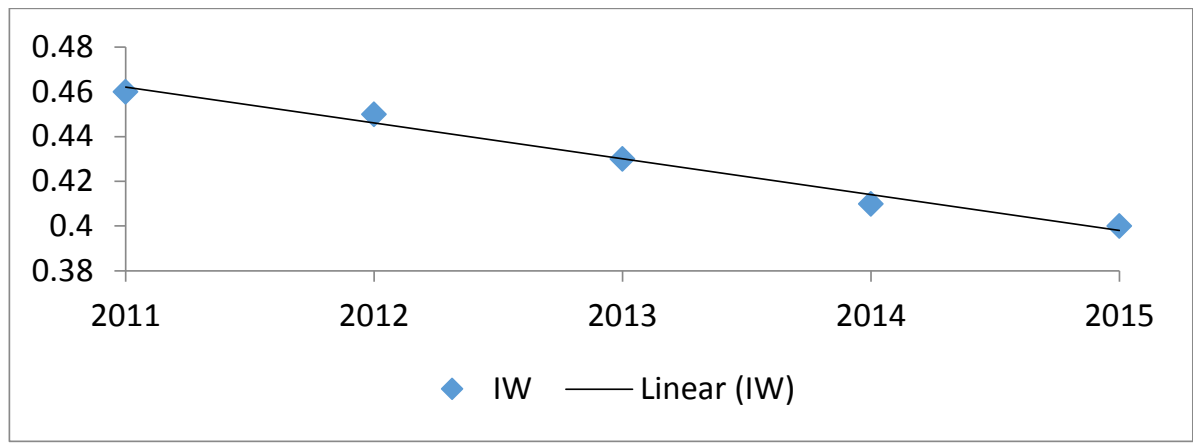

Sumber: Hasil analisis

Gambar 2. Nilai Indeks Williamson periode 2011-2015

Walaupun dalam hal ini bisa dikatakan perubahan nilai indeks tidak terlalu signifikan akan tetapi perlu diapresiasi. Hal ini menunjukkan bahwa pembangunan ekonomi antar kabupaten/kota semakin baik. Pembangunan ekonomi yang merata akan dapat mengurangi ketimpangan ekonomi antar wilayah, jangan terlalu dipacu pertumbuhan ekonomi pada wilayah-wilayah yang sudah maju dan berkembang pesat. Dengan adanya pembangunan ekonomi yang tepat guna, maka akan mampu meningkatan pendapatan perkapita masyarakat, sehingga pemerataan pendapatan juga dapat ditingkatkan. Dalam mengukur ketimpangan pendapatan menggunakan analisis indeks Gini Ratio.

Dari tabel 2 dapat dilihat bahwa terdapat hasil yang berbeda-beda terhadap distribusi pendapatan baik antar wilayah maupun pertahunnya. Pada tahun 2015 semua kabupaten/kota mengalami ketimpangan pendapatan yang semakin meningkat kecuali di Kota Sabang mengalami penurunan dibandingkan dari tahun-tahun sebelumnya dan Kota Lhokseumawe yang trennya terus menurun dari Tahun 2012. Pada Tahun 2011 Kabupaten Pidie merupakan kabupaten yang paling rendah ketimpangan pendapatannya yaitu sebesar 0,19 , akan tetapi terjadi peningkatan yang sangat tinggi pada tahun berikutnya 0,41 padah Tahun 2012. Begitu juga dengan beberapa kabupaten/kota lainnya, misalnya Kabupaten Subulussalam yang terjadi peningkatan sebesar 0,30 pada tahun 2012. Sama halnya dengan Kota Lhokseumawe yang awalnya 0,3 menjadi 0,54, Kota Sabang pada Tahun 2011 sebesar 0,24 naik menjadi 0,52, Kota Banda Aceh dari 0,31 menjadi 0,51, Kabupaten Pidie Jaya juga sama 0,25 menjadi 0,5, Kabupaten Bener Meriah dari 0,23 menjadi 0,49 dan beberapa kabupaten/kota lainnya yang mengalami peningkatan pendapat yang terlalu tinggi pada Tahun 2012. Semua kabupaten/kota yang terdapat di Provinsi Aceh mengalami peningkatan Indek Gini Ratio pada Tahun 2012. Pada tahun-tahun selanjutnya terjadi naik turun seperti biasa.

Tabel 2. Indek Gini Ratio Aceh 2011-2015 


\begin{tabular}{|c|c|c|c|c|c|c|}
\hline No. & $\mathrm{Kab} /$ Kota & 2011 & 2012 & 2013 & 2014 & 2015 \\
\hline 1 & Simeulue & 0.33 & 0.33 & 0.27 & 0.28 & 0.36 \\
\hline 2 & Aceh Singkil & 0.24 & 0.34 & 0.28 & 0.31 & 0.33 \\
\hline 3 & Aceh Selatan & 0.27 & 0.35 & 0.24 & 0.26 & 0.31 \\
\hline 4 & Aceh Tenggara & 0.25 & 0.36 & 0.21 & 0.25 & 0.3 \\
\hline 5 & Aceh Timur & 0.23 & 0.37 & 0.24 & 0.24 & 0.32 \\
\hline 6 & Aceh Tengah & 0.25 & 0.38 & 0.31 & 0.29 & 0.3 \\
\hline 7 & Aceh Barat & 0.25 & 0.39 & 0.3 & 0.31 & 0.36 \\
\hline 8 & Aceh Besar & 0.29 & 0.4 & 0.3 & 0.29 & 0.31 \\
\hline 9 & Pid i e & 0.19 & 0.41 & 0.2 & 0.23 & 0.27 \\
\hline 10 & Bireuen & 0.26 & 0.42 & 0.29 & 0.29 & 0.32 \\
\hline 11 & Aceh Utara & 0.25 & 0.43 & 0.22 & 0.25 & 0.27 \\
\hline 12 & Aceh Barat Daya & 0.26 & 0.44 & 0.25 & 0.26 & 0.27 \\
\hline 13 & Gayo Lues & 0.25 & 0.45 & 0.26 & 0.28 & 0.3 \\
\hline 14 & Aceh Tamiang & 0.24 & 0.46 & 0.21 & 0.26 & 0.28 \\
\hline 15 & Nagan Raya & 0.23 & 0.47 & 0.23 & 0.28 & 0.27 \\
\hline 16 & Aceh Jaya & 0.28 & 0.48 & 0.27 & 0.31 & 0.34 \\
\hline 17 & Bener Meriah & 0.23 & 0.49 & 0.23 & 0.24 & 0.28 \\
\hline 18 & Pidie Jaya & 0.25 & 0.5 & 0.24 & 0.23 & 0.24 \\
\hline 19 & Banda Aceh & 0.31 & 0.51 & 0.28 & 0.29 & 0.33 \\
\hline 20 & Sabang & 0.24 & 0.52 & 0.31 & 0.29 & 0.27 \\
\hline 21 & Langsa & 0.37 & 0.53 & 0.31 & 0.34 & 0.37 \\
\hline 22 & Lhokseumawe & 0.3 & 0.54 & 0.32 & 0.33 & 0.32 \\
\hline 23 & Subulussalam & 0.25 & 0.55 & 0.32 & 0.3 & 0.37 \\
\hline
\end{tabular}

Sumber: BPS Aceh, 2016

\section{Pengaruh Infrastruktur Terhadap Ketimpangan Pembangunan Ekonomi Wilayah}

Dalam mengestimasi model maka perlu dilakukan pemilihan metode regresi. Pemilihan metode regresi dilakukan dengan dua tahap yaitu pertama, membandingkan pooled model dengan fixed effects modelyang menggunakan uji Chow.

Redundant Fixed Effects Tests

Test cross-section fixed effects

\begin{tabular}{crrr}
\hline Effects Test & Statistic & d.f. & Prob. \\
\hline & 2.44924 & & \\
Cross-section F & 4 & $(17,68)$ & 0.0048 \\
\hline
\end{tabular}

Dalam uji Chow hipotesis yang digunakan adalah:

H0: Model Pooled Least Square

H1: Model Fixed Effect

Berdasarkan hasil uji Chow dengan variabel dependen Ketimpangan Pembangunan Ekonomi diketahui bahwa $p$-value sebesar $0.0048<\alpha(0.05)$, maka tolak H0, artinya bahwa penggunaan model Fixed Effect lebih sesuai digunakan dibandingkan model Pooled Least Square.

Tahap kedua, membandingkan fixed effects model dengan random effect model dengan menggunakan uji Hausman. 
Correlated Random Effects - Hausman Test

Test cross-section random effects

\begin{tabular}{cccc}
\hline Test Summary & Chi-Sq. Statistic & Chi-Sq. d.f. & Prob. \\
\hline Cross-section random & 17.800798 & 4 & 0.0013 \\
\hline
\end{tabular}

Dalam uji Hausman hipotesis yang digunakan adalah:

H0: Model Random Effect

H1: Model Fixed Effect

Berdasarkan hasil uji Hausman dengan variabel dependen Ketimpangan Pembangunan Ekonomi diketahui bahwa p-value sebesar $0.0013<\alpha(0.05)$, maka tolak H0. Berdasarkan hasil uji hausman dapat disimpulkan bahwa penggunaan model Fixed Effect lebih sesuai digunakan dibandingkan model Random Effect.

Hasil uji Chow dan uji Hausman menunjukkan bahwa fixed effects model adalah model yang paling tepat. Metode estimasi data panel dengan menggunakan fixed effects model secara umum dilakukan dengan Ordinary Least Squares (OLS). Namun jika terjadi heteroskedastisitas dari data cross section maka dapat digunakan estimasi dengan General Least Square (GLS) atau sering disebut sebagai Cross Section Weights. Jika dalam model dideteksi adanya heterokedastisitas dan korelasi antar unit Cross-Section maka digunakan Cross Section SUR. Untuk mendeteksi adanya heteroskedastisitas dapat dilakukan dengan membandingkan Sum Square Resid pada GLS (weighted) dengan OLS (unweighted). Berdasarkan hasil pengamatan, ditemukan adanya heteroskedastisitas pada model. Oleh karena itu, estimasi dilakukan dengan Cross Section Weights.

Tabel 3. Pengaruh Infrastruktur Terhadap Ketimpangan Pembangunan Ekonomi Wilayah

\begin{tabular}{lll}
\hline \multirow{2}{*}{ Variabel Bebas } & \multicolumn{2}{c}{ Variabel tidak bebas: Ketimpangan Ekonomi Wilayah } \\
\cline { 2 - 3 } & Koefisien & Prob \\
\hline Jalan & -0.009463 & 0.6903 \\
Listrik & -0.012594 & $0.0000^{\star \star}$ \\
Pendidikan & -0.060347 & 0.6983 \\
Kesehatan & 0.046067 & $0.0475^{\star \star}$ \\
\hline R-squared & & 0.485427 \\
Prob(F-statistic) & $:$ Signifikan & 0.000265 \\
** : $5 \%$ & &
\end{tabular}

Pembangunan infrastuktur dapat mendukung aktivitas ekonomi. Apabila pembangunan infrastruktur pada wilayah yang jauh dari pusat pertumbuhan ekonomi dilakukan dengan baik, maka wilayah tersebut akan menjadi pusat pertumbuhan ekonomi yang baru. Dengan sendirinya wilayah tersebut dapat maju dan berkembang mengikuti wilayah-wilayah yang terlebih dahulu maju dan berkembang dari wilayah tersebut. Sehingga ketimpangan antar wilayah dapat dikurangi. Mopangga (2011), menyatakan bahwa sumber utama ketimpangan di Provinsi Gorontalo sangat signifikan disebabkan oleh rasio belanja infratsruktur.

Hasil estimasi menunjukkan bahwa secara statistik jumlah aliran listrik yang tersedia bagi masyarakat di setiap kabupaten/kota di Provinsi Aceh dan jumlah fasilitas kesehatan yaitu jumlah rumah sakit, puskesmas, pustu dan polindes pada taraf nyata $(\alpha) 5$ persen berpengaruh signifikan terhadap ketimpangan pembangunan ekonomi wilayah, sedangkan total panjang jalan yang tersedia di kabupaten/kota di Provinsi Aceh, jumlah fasilitas pendidikan yaitu jumlah sekolah dasar, sekolah lanjutan pertama dan sekolah lanjutan atas tidak berpengaruh signifikan terhadap ketimpangan pembangunan ekonomi wilayah di 
Provinsi Aceh. Nilai R-Square (R2) atau koefisien determinasi dari model sebesar 0,485, nilai tersebut menunjukkan bahwa variasi dalam variabel eksogen yang terdiri dari infrastruktur ekonomi yang terdiri dari variable jalan dan variabel listrik, dan infrastruktur sosial yang terdiri dari variabel pendidikan dan variabel kesehatan menjelaskan 48,5 persen variasi pengaruh infrastrukutur terhadap ketimpangan pembangunan ekonomi wilayah di Provinsi Aceh, sedangkan sisanya sebesar 51,5 persen dijelaskan oleh variabel lain diluar model.

Variabel pertama jalan berpengaruh negatif sebesar 0,009463 terhadap ketimpangan pembangunan ekonomi wilayah, begitu juga dengan veriabel kedua listrik berpengaruh negatif terhadap ketimpangan pembangunan ekonomi wilayah sebesar 0,012594, dan sama halnya dengan variabel ketiga pendidikan berpengaruh negatif sebesar 0,060347 terhadap ketimpangan pembangunan ekonomi wilayah.

Jalan merupakan aspek yang sangat penting dalam peningkatan pertumbuhan ekonomi, khususnya pertumbuhan ekonomi wilayah yang letaknya jauh dari pusat aktivitas ekonomi. Dengan tersedianya jalan yang baik akan mampu meningkatkan produktivas dan aksebilitas barang antar wilayah, sehingga ketimpangan dapat diminimalisir antara pusat aktivitas ekonomi dengan wilayah yang memproduksi hasil pertanian atau wilayah penghasil bahan baku. Panjang jalan merupakan faktor yang sangat penting dalam mengurangi ketimpangan suatu wilayah, karena distribusi barang dan jasa maupun manusia sangat berpengaruh terhadap ketersediaan infrastruktur jalan. Interaksi antar wilayah akan mudah apabila kondisi jalan baik, sehingga mobilisasi faktor produksi maupun hasil produksi akan lebih baik menyebabkan lahirnya pusat pertumbuhan ekonomi baru dan terjadi peningkatan hasil produksi. Mayaningsih (2014) pertumbuhan pendapatan perkapita berdampak signifikan oleh kondisi infrastruktur jalan dan listrik. Apabila pembangunan jalan dan listrik terbangun secara merata sampai keseluruh wilayah dapat memicu keseimbangan ekonomi. Maqin (2011), menyatakan bahwa infrastruktur listrik, tenaga kerja, dan pengeluaran pembangunan mempunyai pengaruh positif dan signifikan terhadap pertumbuhan ekonomi dan merupakan faktor-faktor yang dapat mempengaruhi pertumbuhan ekonomi kabupaten dan kota di Jawa Barat. Kondisi ini menunjukkan bahwa apabila infrastruktur listrik, jumlah tenaga kerja dan pengeluaran pembangunan meningkat, maka berpengaruh pada pertumbuhan ekonomi semakin meningkat begitu juga sebaliknya. Terdapat hubungan positif antara infrastruktur jalan dan infrastruktur pendidikan, akan tetapi tidak signifikan. Sedangkan infrastruktur kesehatan memiliki hubungan yang negatif dan tidak signifikan.

Pendidikan juga ikut mengambil peran penting terhadap ketimpangan ekonomi pada suatu wilayah. Hal ini disebabkan oleh IPM dan kreativitas manusia pada suatu wilayah. Sumberdaya manusia ikut berperan dalam pembangunan suatu wilayah, apabila tingkat pendidikan dan ketersediaan infratruktur pendidikan merata maka ketimpangan ekonomi antar wilayah dapat dikurangi. Sesuai dengan Posumah (2015) penelitian yang dilakukan di Minahasa Tenggara pada variabel pendidikan terhadap investasi yang apabila pendidikan menurun maka investasi juga ikut menurun. Secara pola berfikir terbalik apabila pendidikan meningkat maka investasi ikut meningkat, pemerataan pendidikan dapat mengurangi ketimpangan antar wilayah. Wilayah yang kurang maju dapat mengejar ketinggalan dengan meningkatkan fasilitas dan tingkat pendidikan sehingga dapat terjadi pemerataan pembangunan ekonomi wilayah. Hasil penelitian Bustomi (2012) di Provinsi Jawa Tengah selama rentang waktu 2007-2010 memperoleh temuan bahwa terdapat hubungan negatif antara kedua variabel tersebut. Dengan kata lain, meningkat nya pengeluaran pemerintah bidang pendidikan akan diikuti dengan menurunnya ketimpangan pendidikan. Peningkatan pengeluaran tersebut berkontribusi terhadap perbaikan kualitas pendidikan, memberikan kemudahan penduduk untuk mengakses pendidikan, sehingga terdapat kemerataan lulusan pendidikan pada penduduk di atas usia 15 tahun, yang tercermin dari penurunan indeks gini pendidikan. 
Sedangkan variabel keempat kesehatan berpengaruh positif terhadap ketimpangan pembangunan ekonomi wilayah sebesar 0,046067. Variabel kesehatan mendapat hasil yang berbeda dengan penelitian sebelumnya yang dilakukan oleh Trias Dewi Yunisti. Menurut Yunisti (2012), yang menggunakan variabel kesehatan dan pendidikan mengalami perkembangan yang positif untuk Provinsi Banten yang artinya bahwa ketimpangan manusia semakin mengecil di Provinsi Banten. Hasil regresi data panel yang dilakukan di Provinsi Aceh dengan variabel kesehatan berpengaruh positif yang artinya peningkatan fasilitas kesehatan dapat meningkatkan ketimpangan pembangunan ekonomi. Berbeda dengan tingat investasi seperti penelitian yang dilakukan Posumah (2015) di Minahasa Tenggara, apabila tingkat kesehatan menurun maka investasi juga ikut menurun.

\section{KESIMPULAN}

Terdapat ketimpangan pembangunan ekonomi wilayah yang terjadi antar kabupaten/kota di Provinsi Aceh akan tetapi trennya semakin menurun dari tahun 2011 sampai tahun 2015. Terdapat beberapa faktor yang signifikan dapat mempengaruhi ketimpangan pembangunan ekonomi wilayah di Provinsi Aceh, yaitu jumlah aliran listrik yang tersedia bagi masyarakat di setiap kabupaten/kota di Provinsi Aceh dan jumlah fasilitas kesehatan yaitu jumlah rumah sakit, puskesmas, pustu dan polindes. Sedangkan total panjang jalan yang tersedia di kabupaten/kota di Provinsi Aceh, jumlah fasilitas pendidikan yaitu jumlah sekolah dasar, sekolah lanjutan pertama dan sekolah lanjutan atas tidak berpengaruh signifikan terhadap ketimpangan pembangunan ekonomi wilayah di Provinsi Aceh.

\section{DAFTAR PUSTAKA}

Badan Pusat Statistik Aceh. 2016. Aceh Dalam Angka 2016. Aceh.

Badan Perencanaan Pembangunan Daerah Aceh. 2015. Seri Analisis Pembangunan Wilayah Provinsi Aceh 2015. Aceh.

Bustomi MJ. 2012. Ketimpangan Pendidikan Antar Kabupaten/Kota dan Implikasinya Di Provinsi Jawa Tenganh. Economics Development Analysis Journal Volume 1 No 2.

Masykur R D. 2000. Pembangunan Daerah Melalui Pengembangan Wilayah. Materi disampaikan pada Acara Diseminasi dan Diskusi Program-Program Pengembangan Wilayah dan Pengembangan Ekonomi Masyarakat di Daerah pada tanggal 15-16 Mei 2000. Bogor.

Mopangga H. 2011. Analisis Ketimpangan Pembangunan dan Pertumbuhan Ekonomi di Provinsi Gorontalo. Trikonomika Volume 10, No. 1, Juni 2011, Hal. 40-51

Maqin A. 2011. Pengaruh Kondisi Infrastruktur terhadap Pertumbuhan Ekonomi di Jawa Barat. Trikonomika Volume 10, No. 1, Juni 2011, Hal. 10-18

Mayaningsih N. 2014. Pengaruh Infrastruktur terhadap Pertumbuhan Ekonomi Indonesia. Buletin Ekonomi Moneter dan Perbankan Vol. 17, No.1, Juli

Muljono S. 2010. Dampak Pembangunan Infrastruktur Jalan Terhadap Perekonomian dan Distribusi Pendapatan. Intra dan Interregional Kawasan Barat dan Timur Indonesia: Suatu Analisis Model Interregional Social Accounting Matrix. Institut Pertanian Bogor. Bogor. [Tesis].

Posumah F. 2015. Pengaruh Pembangunan Infrastruktur Terhadap Investasi di Kabupaten Minahasa Tenggara. Jurnal Berkala Ilmiah Efisiensi. Volume 15 No. 02 Tahun 2015.

Rustiadi E, Saifulhakim S, Panuju DR, 2009. Perencanaan dan Pembangunan Wilayah. Crestpe press. Jakarta.

Todaro. 2000, Pembangunan Ekonomi di Dunia Ketiga (Edisi Ketujuh), Erlangga, Jakarta.

Yunisti TD. 2012. Analisis Ketimpangan Pembangunan Antar Kabupaten/Kota Di Provinsi Banten. Universitas Indonesia. Jakarta. [Tesis]. 